\title{
Impaired anti-viral immune response to human rhinovirus 1B infection in chronic allergic airway inflammation does not manifest in asthma exacerbation
}

\author{
Sabine Rochlitzer ${ }^{1 *}$, Heinz-Gerd Hoymann ${ }^{1}$, Armin Braun ${ }^{1,2}$, Meike Müller ${ }^{1}$, U-BIOPRED $^{1}$ \\ From 2nd Cross Company Respiratory Symposium \\ Horsham, UK. 6-7 September 2012
}

\section{Background}

Human rhinovirus is most prominently associated with asthma exacerbations in humans. The U-BIOPRED project of the Innovative Medicine Initiative (IMI) aims to define biomarkers of asthma exacerbations. Within this context, this study aimed to establish a mouse model of asthma exacerbations induced by viral respiratory infection on the background of chronic allergic airway inflammation.

\section{Materials and methods}

$\mathrm{BALB} / \mathrm{c}$ mice were sensitized intranasally with house dust mite (HDM) extract ( $25 \mu \mathrm{g}$ in $50 \mu$ l saline) for five days per week over 7 weeks. HRV1b was inoculated intranasally on the final three challenge days 30 minutes prior HDM application. Additionally, animals were treated with fluticasone proprionate daily prior to HDM challenge in the final week to assess steroid efficacy. 24h after the last combined virus/allergen challenge, pulmonary function (lung resistance, RL) was measured invasively to assess airway hyperresponsiveness (AHR) against aerosolized methacholine (MCh). Bronchoalveolar lavage (BAL) differential cell count and cytokines, lung histology and mediastinal lymph node response were analyzed.

\section{Results}

The HDM sensitized animals developed a marked allergen-induced AHR and eosinophilic airway inflammation

\footnotetext{
* Correspondence: sabine.rochlitzer@item.fraunhofer.de

'Fraunhofer Institute for Toxicology and Experimental Medicine, Hannover, Germany

Full list of author information is available at the end of the article
}

compared to the saline control group. Additional rhinovirus infection did not result in an exacerbation phenotype regarding AHR, BAL inflammatory cell counts, draining lymph node cell counts and ex vivo proliferative response. However, a satellite control group of naïve mice infected with HRV1B revealed an impaired anti-viral immune response in animals with chronic airway inflammation, indicated by reduced BALF neutrophil cell counts and cytokine levels of IFN- $\gamma$, IL-12, IL$1 \beta$ and TNF- $\alpha$, as well as ex vivo proliferative response of draining lymph node cells.

\section{Conclusions}

The established model of combined chronic airway inflammation and viral infection failed to mimic the symptoms of exacerbating asthma pathology. Nevertheless, this model was able to show in vivo the impaired anti-viral immune response due to chronic allergic airway inflammation. The failure to induce exacerbation might be due to inefficient replication of rhinovirus in the mouse, therefore the use of other respiratory viruses might succeed in developing exacerbation models. However, the observed impaired anti-viral response in mice with chronic airway inflammation might reflect the basis for an altered progress of the disease, ultimately resulting in a more severe phenotype.

\section{Acknowledgements}

Funded by the Fraunhofer Society and the EU \& EFPIA within the Innovative Medicines Initiative (IMI).

\footnotetext{
Authors' details

${ }^{1}$ Fraunhofer Institute for Toxicology and Experimental Medicine, Hannover, Germany. ${ }^{2}$ Hannover Medical School, Hannover, Germany.
} 
doi:10.1186/1476-9255-10-S1-P20

Cite this article as: Rochlitzer et al:: Impaired anti-viral immune response to human rhinovirus $1 \mathrm{~B}$ infection in chronic allergic airway

inflammation does not manifest in asthma exacerbation. Journal of

Inflammation 2013 10(Suppl 1):P20.

Submit your next manuscript to BioMed Central and take full advantage of:

- Convenient online submission

- Thorough peer review

- No space constraints or color figure charges

- Immediate publication on acceptance

- Inclusion in PubMed, CAS, Scopus and Google Scholar

- Research which is freely available for redistribution

Submit your manuscript at www.biomedcentral.com/submit
C Biomed Central 